\title{
The reduction of avoidance behavior as a function of gentling'
}

H. B. ALTMAN ${ }^{2}$ and L. S. HOMMEL, Califormia State College, Long Beach, Calif. 90801

Forty-five rats were trained to run to a sucrose reward. Following an electric shock in the goal box the experimental groups were gentled. Gentling was administered by the principal $E$ or by an alternate immediately following shock or just prior to the next (test) trial. Gentled groups showed markedly faster approach than the nongentled control group. The pretest gentled groups were significantly faster than the postshock gentled groups. No significant differences involving the principal-alternate $E$ dimension were found. The systematic control of gentling, especially in shock studies, was advised.

In a series of preliminary studies $^{3}$ on approach-avoidance conflict in rats it was found that Ss gentled (petted for about $3 \mathrm{~min}$ ) sometime before a test of the conflict, consistently. showed a significantly greater approach tendency than nongentled Ss.

The procedure for developing the approach-avoidance conflict was essentially that employed by Kaufman \& Miller (1949). Ss were trained to run an alley to a sucrose solution reward. Upon reaching near asymptotic performance, each $S$ received a shock as the reward was taken. Sometime between the shock trial and the test trial, which followed $24 \mathrm{~h}$ later, the experimental Ss were gentled. For various experimental groups the gentling occurred at the following times: immediately after shock (postshock gentling); $8 \mathrm{~h}$ after shock (intermediate gentling); immediately before the first test trial (pretest gentling); or both just after shock and prior to test (postshock-pretest gentling). The control Ss received no gentling.

Gentled groups showed a consistent effect: faster approach to the goal compared to control Ss. The effect of gentling is apparently cumulative as groups which were gentled twice (postshock and pretest) tended to surpass groups gentled only once. The relative performance of the gentled vs control groups persisted over a sequence of several test trials. However, all groups tended to retum to their preshock performance level.

As an initial working hypothesis it was assumed that gentling establishes a state in the animal which interferes with emotional remnants of shock and with the conditioned evocation of fear. Thus, pretest gentling would be incompatible with fear evoked by the shock-associated cues of the runway on the first test trial. Postshock gentling was originally thought to disrupt the consolidation following the shock trial. However, the approximately equal effect of intermediate gentling required a different hypothesis. Both postshock and intermediate gentling may operate as unconditioned stimuli. The brief handling required to place the $S$ into the experimental apparatus on the test trial may be considered a CS which would evoke a conditioned version of the reaction to gentling. This hypothesis provides a clear prediction of the superiority of pretest gentling over postshock gentling. Such a difference was suggested by the preliminary studies.

If postshock gentling is done by someone other than the regular $\mathrm{E}$, the E's handling on the test trial would constitute a generalized CS. Thus, postshock gentling by an alternate $\mathrm{E}$ should be less effective than gentling by the principal $E$. It was expected that a similar difference might not exist in the case of pretest gentling where an unconditioned response to gentling would be involved regardless of who did the gentling. This hypothesized interaction between the time of gentling and person is independent of the relative effectiveness of the two handlers.

\section{SUBJECTS}

Forty-five Long-Evans, pigmented rats, 17 males and 28 females, were obtained from the animal stockroom of the Psychology Department, CSCLB. The Ss were raised from birth with no unnecessary handling and were 70 to 80 days old at the onset of training.

\section{APPARATUS}

The apparatus consisted of an enclosed straight alley runway, a photocell timing system, and a shock delivery system. The runway was constructed of $1 / 4$-in. unpainted plywood, 8 in. high, 4 in. wide, covered with framed $1 / 4$-in. screen doors. The entire runway was 69 in. long, including two 16.5-in. endboxes (goalbox and startbox) with guillotine doors. Inserted through the back wall of the goalbox was a metal drinking tube containing a $25 \%$ (by weight) sucrose solution. The floor of the goalbox was covered with 1/32-in. wire screening. The drinking tube was connected in series to a $115-\mathrm{V}$.35-amp isolation transformer, a $220-\mathrm{K}$ carbon resistor, and the screen floor of the goalbox. The potential current output was $.5 \mathrm{~mA}$. The circuit was closed when $\mathrm{S}$ attempted to drink.

Running times were measured by a Hunter Klockounter activated by relays (Hunter Model 335S) which were in turn activated by two photocells mounted on the runway. One light-photocell pair was mounted with the beam crossing the alley $10.5 \mathrm{in}$. beyond the startbox guillotine door; the other light-photocell pair was 10.5 in. inside the goalbox.

\section{PROCEDURE}

All Ss were pretrained to run to the sucrose solution under $14 \mathrm{~h}$ of water deprivation, two trials per day for four days. Thereafter Ss were allowed food and water ad libitum and run one trial per day. A standard training trial consisted of placing $S$ in the startbox and allowing it to run to the goal. The guillotine doors were lowered in the course of the trial to prevent retracing. S was allowed $15 \mathrm{sec}$ in the goalbox.

Following Trial 28, logarithmic scores based on running times for Trials 24-28 were used to form five groups (nine Ss per group) which were approximately equal in mean and variance (see Table 1). The groups were given the following

Table 1

Means and Standard Deviations based on $\log _{10}$. (run time in seconds +1.00 ) for Terminal Training, Shock, and Test Trials

\begin{tabular}{cccc}
\hline Group & $\begin{array}{l}\text { Training } \\
\text { Trials } \\
(2428)\end{array}$ & $\begin{array}{l}\text { Shock } \\
\text { Trial } \\
(29)\end{array}$ & $\begin{array}{l}\text { Test } \\
\text { Trial } \\
(30)\end{array}$ \\
\hline PT Mean & .40 & .39 & .36 \\
S.D. & .041 & .037 & .075 \\
AT Mean & .41 & .40 & .43 \\
S.D. & .046 & .042 & .082 \\
PS Mean & .40 & .41 & .68 \\
S.D. & .055 & .046 & .095 \\
AS Mean & .40 & .41 & .92 \\
S.D. & .043 & .037 & .122 \\
C Mean & .40 & .42 & 1.84 \\
S.D. & .051 & .040 & .145 \\
\hline
\end{tabular}


designations by a random process: Group C, nongentled control group; Group PT, gentled by principal E immediately prior to the test trial; Group PS, gentled by principal E immediately after the shock trial; Group AT, gentled by alternate $E$ prior to the test trial; and Group AS, gentled by alternate $E$ after the shock trial.

On Trial 29, each $S$ received a shock when it attempted to drink in the goalbox. Each S of the C, PT, and AT groups was immediately removed from the goalbox and returned to its home cage by the principal $E$ (except where indicated otherwise, all handling was by the principal E). The Ss of Group PS were removed from goalbox, set down on the apparatus table, picked up by the principal $\mathrm{E}$ and gentled, returned to the apparatus table, picked up again and returned to the home cage. The procedure for Group AS was equivalent except that it was the alternate $E$ who took $S$ from the table, gentled it, and replaced it on the table.

On the following day ( $24 \mathrm{~h}$ later), prior to the test trial, each $S$ of Group PT was taken from its cage, placed on the table, picked up and gentled, replaced on the table, picked up and given a trial in the runway. The procedure for Group AT was equivalent except that the alternate $E$ did the gentling. For all groups the test trial was equivalent to a training trial except that $S$ was removed from the apparatus if it did not enter the goalbox within 99 sec.

Gentling consisted of holding $S$ close to E's body and stroking the back from head to tail, 30 to 40 strokes per minute for $3 \mathrm{~min}$.

The principal $\mathrm{E}$ was a 27 -year-old male. The alternate $\mathrm{E}$ was a 24-year-old female. The alternate $E$ did not have any contact with the Ss prior to the shock trial.

\section{RESULTS}

The running times (in seconds) for Trials 24-30 were converted to logarithmic equivalents after adding 1.00 to each score. A mean was calculated for each S over Trials 24-28. The group means based on these scores (which were deliberately equated prior to Trial 29) are reported in Table 1 along with group means for Trial 29 (shock trial) and Trial 30 (test trial). It can be seen that the groups maintained their similarity on Trial 29 whereas the effects of shock and gentling are apparent on Trial 30.

As expected, gentled groups showed faster approach than the control group. A total of six Ss in the control group failed to enter the goalbox within $99 \mathrm{sec}$; this nonentry behavior was not exhibited by the other groups. The pretest gentled groups showed essentially no decrement in performance from shock trial to test trial.

A series of planned comparisons (Hays, 1963) on the test trial data revealed the following: The gentled groups as a whole differed significantly from the control group $(F=173.4, \mathrm{df}=1 / 40, \mathrm{p}<.001)$; the pretest gentled groups were significantly faster than the postshock gentled groups $(\mathrm{F}=23.4, \mathrm{df}=1 / 40, \mathrm{p}<.001)$; no significant interaction was found between person and time of gentling $(F<1.00)$; a test of alternate and principal $E$ differences also failed to attain the customary $5 \%$ level of significance $(F=3.3662, \mathrm{df}=1 / 40$, $\mathrm{p}<.10$ ). All comparisons are two-tailed.

\section{DISCUSSION}

The superiority of the handled groups over controls appears to support an emotionality-fear interference hypothesis. There are many studies of infantile handling or gentling in the rat (cf. Denenberg \& Haltmeyer, 1967) indicating similar effects upon the rat's adult behavior. However, Bovard (1958) in discussing this phenomenon considers conflicting interpretations of early gentling as a source of stress and as a stress reducer. Studies of gentling in the adult rat also lead to contradictory interpretations. Sperling \& Valle (1964) report no great difficulty developing gentling as a secondary positive reinforcer. And yet, several attempts (cf. Candland, Horowitz, \& Culbertson, 1962) to investigate the primary reinforcing effects of gentling have indicated its negative value.

It may be hypothesized that the emotional effects of gentling are not constant but depend on previous experience and the context within which the gentling occurs. In particular, gentling in the context of emotionality or fear may have a calming effect on the animal. This is perhaps homologous to the calming effects of contact comfort in the young monkey (Harlow \& Zimmermann, 1959).

While the difference between postshock and pretest gentled groups supports the conditioning hypothesis, the lack of interaction does not. The experimental manipulation required to equate the gentling procedure for the principal and alternate Es may have introduced some conditioned response aspects into the pretest effects. Interference with consolidation remains as a possible interpretation of the postshock gentling effects.

The contaminating effects of uncontrolled gentling stressed by Christie (1951) and supported by the studies previously mentioned is strikingly demonstrated in the present study. Extreme caution and control of gentling, especially in shock studies, is indicated.

\section{REFERENCES}

BARRY, $H$, III. Habituation to handling as a factor in maze performance in rats. Journal of Comparative \& Physiological Psychology, 1957, 50, 366-367.

BOVARD, E. W. The effects of early handling on the viability of the albino rat. Psychological Review, 1958, 65, 257-271.

CANDLAND, D. K., HOROWITZ, S. H., \& CULBERTSON, J. L. Acquisition and retention of acquired avoidance with gentling as reinforcement. Journal of Comparative \& Physiological Psychology, $1962,55,1062-1064$.

CHRISTIE, R. Experimental naivete and experiential naivete. Psychological Bulletin, 1951, 4, 327-339.

DENENBERG, V. H., \& HALTMEYER, G. C. Test of the monotonicity hypothesis concerning infantile stimulation and emotional reactivity. Journal of Comparative \& Physiological Psychology, 1967, 63, 394-396.

HARLOW, H., \& ZIMMERMANN, R. R. Affectional responses in the infant monkey. Science, $1959,130,421-432$.

KAUFMAN, E. L., \& MILLER, N. E. The effect of number of reinforcements on strength of approach-avoidance conflict. Journal of Comparative and Physiological Psychology, 1949, 42, 65-74.

SPERLING, S. E., \& VALLE, F. P. Handling-gentling as a positive secondary reinforcer. Journal of Experimental Psychology, 1964, 67, 573-576.

\section{NOTES}

1. This study is a report of a thesis submitted by H. B. Altman in partial fulfillment of the requirements for the degree of Master of Arts to the Department of Psychology, California State College at Long Beach.

2. Now at Douglas Aircraft Company, Department of Sciences Research, Long Beach, California.

3. To our knowledge R. C. Willihnganz first demonstrated the effect of gentling upon conflict behavior. The preliminary studies referred to were run with his cooperation and assistance. 